OPEN ACCESS

Edited by:

Jorge I. Mardones,

Instituto de Fomento Pesquero

(IFOP), Chile

Reviewed by:

Sai Elangovan S.,

National Institute of Oceanography

(CSIR), India

Kathryn Coyne,

University of Delaware, United States

*Correspondence:

Lourdes Morquecho lamorquecho@cibnor.mx

Specialty section: This article was submitted to Marine Ecosystem Ecology, a section of the journal Frontiers in Marine Science

Received: 01 July 2018 Accepted: 07 January 2019 Published: 23 January 2019

Citation: Morquecho L (2019) Pyrodinium bahamense One the Most Significant

Harmful Dinoflagellate in Mexico. Front. Mar. Sci. 6:1 doi: 10.3389/fmars.2019.00001

\section{Pyrodinium bahamense One the Most Significant Harmful Dinoflagellate in Mexico}

\author{
Lourdes Morquecho* \\ Centro de Investigaciones Biológicas del Noroeste, La Paz, Mexico
}

Pyrodinium bahamense produces saxitoxins and can cause paralytic shellfish poisoning (PSP). This species has caused more human illnesses and fatalities than any other toxic dinoflagellate in Mexico. The distribution of dinoflagellate cysts with their vegetative stage is broad, mainly along Mexican Pacific coasts from the central Gulf of California to Chiapas, as well as in the southern Gulf of Mexico and the Mexican Caribbean Sea on the Atlantic coast. In vitro germination of living cysts from the southern Gulf of California occurs under thermophilic $\left(20-35^{\circ} \mathrm{C}\right)$ and euryhaline (20-35 ups) conditions. Blooms occurred typically during summer rainy season (June through September), inside of restricted shallow lagoons surrounded by mangrove forests. The data obtained so far on $P$. bahamense spatial and population variability in Mexican Pacific and the Gulf of Mexico, suggest a seasonal and latitudinal pattern. Also, in these regions, the abundance, seasonality, and species distribution tend to decrease from tropical to subtropical areas. The local strain toxicity has only been corroborated in one isolate from the southern Gulf of California, which exhibited a high saxitoxin concentration of 95 pg STX eq cell ${ }^{-1}$. PSP outbreaks linked with $P$. bahamense in the Gulf of Tehuantepec from 1989 to 2007, caused at least 200 human cases, with 15 fatalities. This mini-review ends with a viewpoint of management and research strategies to better understand the factors that play essential roles in the bloom dynamics and toxicity of this species.

Keywords: Pyrodinium bahamense, Mexico, harmful blooms, saxitoxins, PSP

\section{INTRODUCTION}

Pyrodinium bahamense Plate is a tropical/subtropical euryhaline dinoflagellate that produces saxitoxins and can cause paralytic shellfish poisoning (PSP). This species has caused more human illnesses and fatalities than any other paralytic shellfish toxin (PST) producing dinoflagellate, with a spate of toxic blooms in the Indo-Pacific and the Pacific coast of Central America (Usup et al., 2012). Pyrodinium bahamense, along with toxic Gymnodinium catenatum Graham, have caused direct adverse consequences for human health, aquaculture industries, tourism, and ecosystem functions in Mexican coastal waters (Hernández-Becerril et al., 2007; García-Mendoza et al., 2016). Pyrodinium bahamense has particular importance since it has caused a significant impact on human health, mainly in southern Mexican Pacific. The effect of harmful algae could be increasing and expand as a consequence of increasing local marine eutrophication (Heisler et al., 2008) and ocean climate change (Hallegraeff, 2010). 
Globally $P$. bahamense is mainly distributed in tropical areas of both hemispheres. The vegetative stage has been reported into three regions, the Caribbean Sea and Central America, Persian Gulf and the Red Sea, and the western Pacific; while cyst stage distribution is broader, primarily in tropical to subtropical coastal areas from both the Atlantic and Pacific regions, and the Caribbean Sea (Usup et al., 2012). Pyrodinium bahamense, is one of the most critical harmful algal bloom (HABs) organisms in South Asian coastal waters (Mertens et al., 2015).

Pyrodinium bahamense is characterized by a high bioluminescence (Seliger et al., 1971), a heterothallic sexual cycle (Wall and Dale, 1969), and a simple toxins profile (dcSTX, STX, neoSTX, B1 and B2) (Usup et al., 2012). In 1980, the species taxonomic status was raised to variety, based on morphological variations in the motile stage, the capability of PSP toxin production, and the geographic distribution (Steidinger et al., 1980). However, based on morphologic and phylogenetic analysis of specimens (motile and cyst stages) from 13 coastal areas of various tropical and subtropical waters, Mertens et al. (2015) demonstrated that there is no consistent criterion to separate unequivocally both varieties based only in morphology. Additionally, Mertens et al. (2015) revealed within the Pyrodinium clade, both Indo-Pacific and Atlantic-Caribbean ribotypes, suggesting that $P$. bahamense is a species complex.

According to Balech (1985), P. bahamense cells are polyhedral and irregularly rounded, with strong crests along the sutures and tend to be compressed when they are in chains. Most cells have a well-developed left antapical spine and a smaller right spine that is an extension of the sulcal list (Figure 1A). The theca has a granular surface and numerous trichocyst pores, there is a pore in the $4^{\prime}$ apical plate, and the apical pore complex consists of a comma-shaped granular closing plate and 9-14 pores. Cysts are spherical, of chorate type, with $\sim 152$ oblate tubular processes of variable length and randomly arranged (Figures 1D,E). The colorless wall is bi-layered, with a scabrate outer surface and a smooth inner surface. In living cysts, the yellow-green cytoplasm encloses a red accumulation body (Figure 1D) and numerous starch grains (Morquecho et al., 2014). Vegetative stage is easy to identify with basic microscopy equipment, and it could hardly be confused with other species. By contrast, due to its similarity with the cysts of other dinoflagellates, the resting stage may be confused with other species.

Blooms of $P$. bahamense are generally aperiodic and unpredictable (Usup et al., 2012); nevertheless, on a large temporal scale, there is some evidence that significant blooms overlap with peaks of El Niño and La Niña cycles (Maclean, 1989; Usup and Azanza, 1998; Phlips et al., 2006). Even though, no relationship has been established between blooms and these cycles, the enhanced delivery of nutrients into the coastal waters could be a factor (Usup et al., 2012). Despite species seasonality that vary with local physiography, hydrography, and climate (Usup et al., 2012), blooms are more predictable at a smaller and local scale (Azanza and Taylor, 2001). Critical elements such as environmental factors, specifically removal of topdown predators and a change from eutrophic to oligotrophic conditions, likely promote the dominance and toxicity of $P$. bahamense in Florida (Walsh et al., 2011).
In this mini-review, the most significant information about Pyrodinium bahamense in Mexico since 1942 to date is summarized and analyzed. Aspects such as vegetative and cyst stage distribution, Mexican strains physiology and toxicology, as well as ecology and bloom dynamics, toxicity, human illnesses, and other significant impacts are discussed. Also, research priorities will be proposed to support the establishment of the guidelines for a transnational scientific approach, which is needed to coordinate and advance the understanding and management of HABs in coastal areas of Latin America.

\section{METHODOLOGY USED IN MEXICO TO STUDY AND MONITOR TO Pyrodinium bahamense}

In Mexico, $P$. bahamense studies focus on the vegetative stage taxonomy, occurrence, and distribution, as well as HABs recordings. Research on ecology, bloom dynamics, toxicology, and genetic characterization is minimal. Until now short-term studies have been undertaken, and there is no permanent scientific monitoring.

Basic methodologies such as water samplers (quantitative analysis), plankton nets (20 $\mu \mathrm{m}$, qualitative analysis), as well as, segmented tubes are applied to obtain marine phytoplankton sample collection at the superficial level or along the water column. For sample preservation, both Lugol and neutralized formalin are used (Throndsen, 1978), and in few cases, the combination of these fixatives is considered to preserve samples for long periods. For quantitative analysis, light microscopy is used to estimate the cell density by the Utermöhl (Hasle, 1978) or Sedgewick-Rafter (Guillard, 1978) methods.

Concerning ambient variables, the record of in situ hydrological variables such as temperature and salinity are the most common, while nutrients rarely are considered. Basic water quality sonde or CTD is the regular multiparameter equipment to record these variables. Nutrients analysis is carried out with standard chemical analytical methods (Strickland and Parsons, 1972).

Research on $P$. bahamense cysts is mainly developed with palynological procedures (de Vernal et al., 2010). Marine sediments are collected with gravitational corers or boxes, and scuba dive is also used to collect surface sediments or corers by hand. Biological procedures to clean and concentrate cysts (Matsuoka and Fukuyo, 2000) has been used for identification, quantification, germination assays, and strains establishment.

The identification of species is carried out by different techniques such as light and scanning electron microscopy, which allows the morphological and theca arrangement observations. It is worth noting that although Mertens et al. (2015) showed that there was no basis for distinction of two species varieties of $P$. bahamense, some researchers still accept this taxonomic status.

For research purposes, shellfish toxicity is determined by standard mouse bioassay (AOAC, 1995), and high-performance liquid chromatography (HPLC-FD with pre-column oxidation) (AOAC, 2005; Lawrence et al., 2005). For food safety, health authorities use the standard AOAC mouse bioassay 


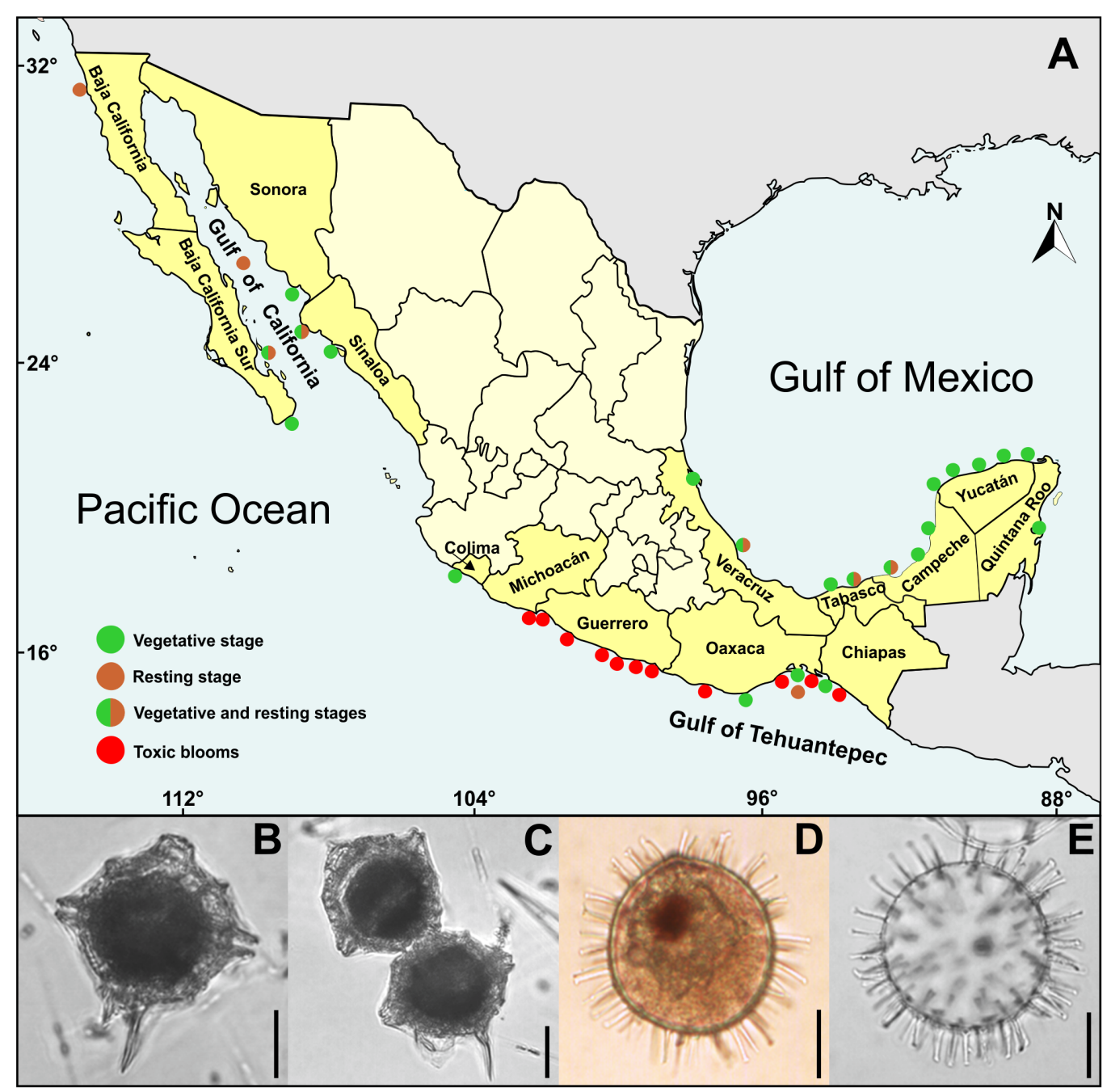

FIGURE 1 | Pyrodinium bahamense in Mexico: (A) Distribution map based on data documented by: Osorio-Tafall (1942); Martínez-Hernández and Hernández-Campos (1991); Saldate-Castañeda et al. (1991); Cortés-Altamirano et al. (1993); Gómez-Aguirre (1998a,b); Ronsón-Paulin (1999); Peña-Manjarrez et al. (2001, 2005); Licea et al. (2004); Terán-Suárez et al. (2006); Martínez-López et al. (2007); Morquecho (2008); Vásquez-Bedoya et al. (2008); Limoges et al. (2010, 2013); Gárate-Lizárraga and González-Armas (2011); Gárate-Lizárraga et al. (2011, 2013); Meave-del Castillo et al. (2012); Morquecho et al. (2012); Merino-Virgilio et al. (2014); Poot-Delgado et al. (2014); Alonso-Rodríguez et al. (2015); Maciel-Baltazar (2015); Poot-Delgado (2016); Campos-Campos et al. (2017), and Cuellar-Martínez et al. (2018). (B) Solitary vegetative cell. (C) Paired vegetative cells. (D) Whole living cyst with red accumulation body. (E) Empty cyst showing chorate processes. Scale bars $=20 \mu \mathrm{m}$.

(AOAC, 1995) and fast track probes (Scotia Rapid Tests) to estimate PSP toxins concentration in shellfish monthly. Phytoplankton samples are collected weekly and abundances $\geq 5 \times 10^{3}$ cells $\mathrm{L}^{-1}$ of $P$. bahamense are considered a potential indicator of toxins accumulation in shellfish ${ }^{1}$.

\section{GEOGRAPHIC DISTRIBUTION}

The first report of $P$. bahamense on Chiapas coast, in southern Mexican Pacific (Figure 1A), came from Osorio-Tafall (1942). At that time, it was believed that the species had a distribution

${ }^{1}$ https://www.gob.mx/cofepris/acciones-y-programas/marea-roja-76038 restricted to the Bahamas; however, at present, the vegetative stage (Figures 1B,C) is distributed in almost all coastal margin of Gulf of Mexico, Caribbean Sea, Gulf of California, and Mexican Pacific (Figure 1A). Cysts (Figures 1D,E) have been reported in limited areas, both Mexican Pacific as in the Gulf of Mexico (Figure 1A). However, it is highly probable that its distribution is as broad as that of vegetative cells, considering that $P$. bahamense cysts have been found in the central Gulf of California (Martínez-Hernández and HernándezCampos, 1991), and in Baja California northern limit (PeñaManjarrez et al., 2001, 2005) (Figure 1A). Despite these findings, a limited distribution of $P$. bahamense cysts has been reported (Martínez-Hernández and Hernández-Campos, 1991), restricted only to Guaymas basin phosphorite sediments, where it was 
TABLE 1 | Pyrodinium bahamense blooms associated with human PSP outbreaks and wildlife mortalities in Mexican Pacific.

\begin{tabular}{|c|c|c|c|c|c|}
\hline Localities & Month/year & $\begin{array}{c}\text { In situ maximum } \\
\text { dinoflagellate } \\
\text { abundance (cells } \mathrm{L}^{-1} \text { ) }\end{array}$ & $\begin{array}{l}\text { Shellfish toxicity ( } \mu \text { g STX } \\
\text { eq } \mathbf{k g}^{-1} \text { ) }\end{array}$ & Impacts & Reference \\
\hline Oaxaca and Chiapas & $12 / 1989$ & $1.7 \times 10^{6}$ & $\begin{array}{l}8,110 \text { (Crassostrea } \\
\text { iridescens) } \\
5,420 \text { (Choromytilus } \\
\text { palliopunctatus) }\end{array}$ & $\begin{array}{l}99 \text { human intoxications } \\
3 \text { fatalities }\end{array}$ & $\begin{array}{l}\text { Saldate-Castañeda } \\
\text { et al., 1991; } \\
\text { Cortés-Altamirano } \\
\text { et al., } 1993\end{array}$ \\
\hline Oaxaca (Huatulco) & $12 / 1990$ to $01 / 1991$ & ND & ND & 6 human fatalities & $\begin{array}{l}\text { Cortés-Altamirano } \\
\text { et al., } 1995\end{array}$ \\
\hline Oaxaca & $11 / 2001$ & $1.14 \times 10^{6}$ & 14,560 (Mytella arciformis) & $\begin{array}{l}17 \text { human intoxications } \\
3 \text { fatalities }\end{array}$ & $\begin{array}{l}\text { Gárate-Lizárraga et al., } \\
2008\end{array}$ \\
\hline $\begin{array}{l}\text { Oaxaca (La Colorada and } \\
\text { La Ventosa) }\end{array}$ & 06/2010 to 02/2011 & ND & ND & 23 human intoxications & COFEPRIS, 2018 \\
\hline Guerrero & $07-08 / 2010$ & ND & ND & 16 human intoxications & COFEPRIS, 2018 \\
\hline Guerrero (Costa Grande) & $12 / / 2010$ & $410 \times 10^{3}$ & $\begin{array}{l}1,460-5,360 \text { (rock oyster) } \\
25,410 \text { (unidentified clam) }\end{array}$ & $\begin{array}{l}12 \text { human intoxications } \\
\text { by ingesting raw and } \\
\text { cooked clam }\end{array}$ & $\begin{array}{l}\text { Gárate-Lizárraga et al., } \\
2011\end{array}$ \\
\hline $\begin{array}{l}\text { Guerrero (Bahía de } \\
\text { Acapulco) }\end{array}$ & $07 / 2010$ to $01 / 2011$ & $773.5 \times 10^{3}$ & $1,000-20,920$ & $\begin{array}{l}\text { Precautionary closure } \\
\text { of fisheries and seafood } \\
\text { consumption }\end{array}$ & $\begin{array}{l}\text { Gárate-Lizárraga et al., } \\
\text { 2012; Meave-del } \\
\text { Castillo et al., } 2012\end{array}$ \\
\hline Guerrero (Costa Chica) & $06-12 / 2010$ & $194 \times 10^{3}$ & $\begin{array}{l}460-7,890 \text { (rock oyster) } \\
520-4,410 \text { (farmed rocky } \\
\text { oysters) }\end{array}$ & $\begin{array}{l}\text { Precautionary closure } \\
\text { of fisheries and seafood } \\
\text { consumption }\end{array}$ & $\begin{array}{l}\text { Gárate-Lizárraga et al., } \\
2013\end{array}$ \\
\hline $\begin{array}{l}\text { Oaxaca (Santiago Astata } \\
\text { and Puerto Escondido) }\end{array}$ & 06/2009 to 06/2010 & $32 \times 10^{3}$ & $\begin{array}{l}\text { Toxins concentration } \\
\text { exceeded the permissible } \\
\text { limit (Striostrea prismatica) }\end{array}$ & $\begin{array}{l}\text { Precautionary closure } \\
\text { of fisheries and seafood } \\
\text { consumption }\end{array}$ & $\begin{array}{l}\text { Alonso-Rodríguez } \\
\text { et al., } 2015\end{array}$ \\
\hline $\begin{array}{l}\text { Guerrero (Bahía de } \\
\text { Acapulco, Costa Chica, } \\
\text { and Costa Grande) }\end{array}$ & $01-02 / 2016$ & ND & ND & $\begin{array}{l}\text { Precautionary closure } \\
\text { of fisheries and seafood } \\
\text { consumption Mortality } \\
\text { of turtles }\end{array}$ & COFEPRIS, 2018 \\
\hline $\begin{array}{l}\text { Oaxaca (seven coastal } \\
\text { municipalities) }\end{array}$ & 02-03/2016 & ND & ND & $\begin{array}{l}\text { Precautionary closure } \\
\text { of fisheries and seafood } \\
\text { consumption Mortality } \\
\text { of turtles and some } \\
\text { cetaceans }\end{array}$ & COFEPRIS, 2018 \\
\hline
\end{tabular}

ND, not documented.

the dominant morphotype (34\%). This distribution is likely attributed to the scarcity of the vegetative stage along the Gulf of California, whereas its presence in the phosphorite, could indicate the influence of slightly hypersaline and tropical warmer water masses. To date, it has been demonstrated that cysts have a broader distribution in southern Gulf of California, primarily in restricted coastal lagoons, where it is the dominant morphotype (33-86\%) (Morquecho et al., 2012; Cuellar-Martínez, 2018; Cuellar-Martínez et al., 2018).

In Gulf of Tehuantepec, and Gulf of Mexico P. bahamense cysts are also one of most dominant morphotype. For the northern part of the Gulf of Tehuantepec, the dinoflagellate dominates in the upper productivity zone associated with seasonal upwelling (Vásquez-Bedoya et al., 2008). This gulf has an average and a maximum water depth of $\sim 250 \mathrm{~m}$ and $\sim 1,000 \mathrm{~m}$, respectively (Vásquez-Bedoya et al., 2008). During boreal winter (December through April), a strong but intermittent wind blows across central America from the Gulf of Mexico and the Caribbean driving upwelling events (Antoine et al., 1996; Pennington et al., 2006). During these events, the average 0$100 \mathrm{~m} \mathrm{NO}_{3}$ concentration is very high at $18.3 \mu \mathrm{mol} \mathrm{l}^{-1}$ (Pennington et al., 2006), and surface chlorophyll concentrations reaching as high as $2 \mathrm{mg} \mathrm{Chl} \mathrm{m}^{3}$ (Lluch-Cota et al., 1997; McClain et al., 2002). For the Gulf of Mexico, the annual temperature (approximately $25-28^{\circ} \mathrm{C}$ ) is the most critical factor that controls nearshore cyst distribution and where $P$. bahamense achieve very high abundances, notably on the west Florida shelf and in the Mexican lagoons (Limoges et al., 2013).

\section{ECOLOGY AND BLOOMS DYNAMICS}

Pyrodinium bahamense usually blooms during the rainy summer (June through September), in restricted shallow lagoons surrounded by mangrove forests (Licea et al., 2004; Meave-del Castillo et al., 2012; Morquecho et al., 2012; Merino-Virgilio et al., 2014), with coastal underground drainage (Gómez-Aguirre, 1998b).

In the southern Gulf of Mexico, P. bahamense appears to have a continuous distribution and occurrence in a wide salinity range (3-38 ups) throughout the year, reaching densities of up to $1.5 \times 10^{6}$ cells L $^{-1}$ Gómez-Aguirre (1998a). In contrast, in the southern Gulf of California, moderate $\left(63-151 \times 10^{3}\right.$ cells $\left.\mathrm{L}^{-1}\right)$, and short-term blooms are influenced by a short summer 
rainy season (August-September), relatively high seawater temperature $\left(25-32^{\circ} \mathrm{C}\right)$, typical salinity (31-36 ups), intense sunlight, and relatively high concentrations of ammonium (0.37$33.04 \mu \mathrm{M})$ and phosphates $(0.68-2.87 \mu \mathrm{M})$; the last one, in turn, depending on rainfall and runoff and seems stronger on the eastern side of the gulf (Morquecho et al., 2012).

In southern Mexican Pacific and the Gulf of Tehuantepec, $P$. bahamense harmful blooms, with cell densities of up to $3 \times 10^{6}$ cells $\mathrm{L}^{-1}$, have occurred from summer to winter (see Table 1) and have been associated with upwelling events (Cortés-Altamirano et al., 1993). The local winds "tehuanos", and currents systems can move the dinoflagellate towards Mexico along the Central Pacific Coast through the Costa Rica Current Flow and Mexican Western Current (Vargas-Montero et al., 2008).

In Mexican coasts, $P$. bahamense has co-occurred with the diatom Pseudo-nitzschia spp. (Morquecho, 2008), and other dinoflagellates such as Ceratium furca, C. dens, Dinophysis caudata, G. catenatum, Margalefidinium polykrikoides, Polykrikos sp., Prorocentrum lima, P. gracile, Protoperidinium oceanicum and P. pellucidum (Terán-Suárez et al., 2006; Gárate-Lizárraga et al., 2011; Meave-del Castillo et al., 2012). Interactions or environmental factors that may promote these co-occurrence has not yet been clarified. However, a similar co-occurrence between P. bahamense and Pseudo-nitzschia species has also been reported in the Indian River Lagoon, Florida (Phlips et al., 2004).

\section{MEXICAN STRAINS TOXICITY AND CYSTS GERMINATION CHARACTERISTICS}

Ecophysiological studies with regional $P$. bahamense strains are insufficient in México, and so far, strains from Isla San José, Gulf of California have only been studied. To elucidate the toxicity of vegetative cells grown from cyst germination, Morquecho et al. (2014) analyzed nine strains through fluorescence highperformance liquid chromatography, and only one exhibited toxicity with high saxitoxin concentration (95 pg STX eq cell ${ }^{-1}$ ). Additionally, morphological features and size of cysts agreed with previous descriptions, particularly morphotypes found in the subtropical North Atlantic. Cysts germination exhibit thermophilic $\left(20-35^{\circ} \mathrm{C}\right.$ with the peak between 25 and $\left.30^{\circ} \mathrm{C}\right)$ and euryhaline characteristics (salinities from 20 to 35 ups). Also, the in vitro germination is improved in growth medium enriched with terrestrial soil extract and selenium.

\section{TOXICITY AND IMPACTS}

Pyrodinium bahamense has caused more human illnesses and fatalities than any other PST producing dinoflagellate in Mexico (Table 1). Southeast Mexican Pacific has been the most affected area, particularly the Gulf of Tehuantepec, as well as Guerrero and Michoacán (Figure 1 and Table 1). From 1989 to 2007 shellfish toxicity reached concentrations above the permissible limits for human consumption (800 $\mu \mathrm{g}$ STX eq $\mathrm{kg}^{-1}$ ), and consequently caused 200 human cases, with
15 fatalities (Hernández-Becerril et al., 2007). By comparison, Gymnodinium catenatum is another toxic species linked with PSP deaths in Mexico, from 1989 to 2015 has caused, in some localities of the Gulf of California, 37 human PSP cases and three fatalities (Mee et al., 1986; Cortés-Altamirano and Núñez-Pasten, 1992; Núñez-Vázquez et al., 2016).

According to the registry of Federal Commission for the Protection against Sanitary Risks (COFEPRIS, by its acronym in Spanish) of the 118 HABs that have been reported from 2004 to 2014 in Mexico, 12\% were linked to P. bahamense. The entity most affected was Oaxaca, followed by Guerrero and Chiapas (COFEPRIS, 2018). Pyrodinium bahamense HABs also have been linked to endangered marine fauna (sea turtles and cetaceans) with ecologic importance, leading in some cases to mass mortalities (Table 1), and the establishment of precautionary closures (COFEPRIS, 2018).

\section{DISCUSSION AND CONCLUSION}

The data obtained so far on P. bahamense spatial and population variability in Mexican Pacific and the Gulf of Mexico, suggest a seasonal and latitudinal pattern. From tropical to subtropical regions, the abundance, seasonality, and species distribution, tends to decrease. For example, the dinoflagellate may develop persistent moderate and massive toxic blooms in Guerrero, Oaxaca, and Chiapas coastal margin (Figure 1), which is characterized by a large-scale hydrological and atmospheric influence (Table 1); while in the southern Gulf of California, moderate blooms are restricted to coastal lagoons inhabited by mangroves, and develop only during the summer and the shortterm rainy period. However, comparative research is needed on both coasts of Mexico to define precisely the hydrologic and climatic variables that are triggering $P$. bahamense blooms.

Epidemiological numbers of outbreaks of food poisoning related to $P$. bahamense, reveal that this dinoflagellate is the major source of PSP in Mexico. Monitoring for food safety on the coasts of Mexico, with particular emphasis on aquaculture areas or the exploitation of marine products, requires essential adjustments to validate and strengthen the management and decision-making database. Permanent records of hydrological variables, climate signals, harmful species abundance, seasonal variation, impacts in human and environmental health, as well as economic activities are essential to implement early warnings and minimize impacts.

Frequency and intensity of HABs as well as, the variation in phytoplankton composition toward toxic species have increased throughout the world (Fu et al., 2012). Recent studies suggest that ocean acidification, combined with the limitation of nutrients, or temperature changes, might dramatically increase the toxicity of some harmful groups (Fu et al., 2012). Mexico and Latin America are not immune to this problem as was discussed in this minireview. Pyrodinium bahamense and other toxic dinoflagellates are significantly impacting human and environmental health, as well as having significant impact on economic activities.

The United States of America, the European Union, and other countries such as Australia and New Zealand, have managed 
significant advances to counteract the impact of harmful microalgae. However, the information that we currently have on blooms dynamics, and toxicological and autecological characteristics of harmful species inhabiting Mexico and Latin America is insufficient. This prevents, in the short term, the establishment of management plans to minimize HABs impacts as well as the advance of the understanding and prediction of them.

Short-term perspectives about scientific research and monitoring activities related with $P$. bahamense populations in Mexico and Central America may include:

- Design and implement an interdisciplinary, specific and permanent monitoring program that consider meroplanktonic characteristic of the species and ecosystems comparison.

- Select as target ecosystems the coastal lagoons with and without mangrove populations. Usup et al. (2012) have questioned the significance of the presence or absence of mangrove forests in the distribution pattern of P. bahamense. Also, they have highlighted the importance of carrying out comparative studies between the western Pacific and tropical Atlantic populations, to understand better the factors that play essential roles in the bloom dynamics and toxicity of the species.

\section{REFERENCES}

Alonso-Rodríguez, R., Mendoza-Amézquita, E., Velásquez-López, S. A., Seim, J. A., and Martínez-Rodríguez, V. M. (2015). Florecimientos algales nocivos producidos por Pyrodinium bahamense en Oaxaca, México (2009-2010). Salud. Publica. Mex. 57, 343-351. doi: 10.21149/spm.v57i4. 7578

Antoine, D., André, J. M., and Morel, A. (1996). Oceanic primary production. 2. Estimation at global scale from satellite (coastal zone colour scanner) chlorophyll. Global Biogeochem. Cycles 10, 57-69. doi: 10.1029/95GB0 2832

AOAC (1995). "Paralytic shellfish poison: biological method," in Official Methods of Analysis of AOAC International, ed. P. A. Cunniff (Gaithersburg, MD: AOAC International).

AOAC (2005). Official Method 2005.06. Quantitative Determination of Paralytic Shellfish Poisoning Toxins in Shellfish Using Prechromatographic Oxidation and Liquid Chromatography with Fluorescence Detection. Gaithersburg, MD: AOAC International.

Azanza, R. V., and Taylor, F. J. R. (2001). Are Pyrodinium blooms in the Southeast Asian region recurring and spreading? A view at the end of the millennium. Ambio 30, 356-364. doi: 10.1579/0044-7447-30.6.356

Balech, E. (1985). A redescription of Pyrodinium bahamense plate (Dinoflagellata). Rev. Palaeobot. Palynol. 45, 17-34. doi: 10.1016/0034-6667(85)9 0063-6

Campos-Campos, B., Cortés-Lara, M. C., and Rivas-Acuña, M. G. (2017). Microalgas planctónicas en la laguna costera «El Carmen», Cárdenas, Tabasco, México. Kuxulkab 23, 29-40. doi: 10.19136/kuxulkab.a23n46.2556

COFEPRIS. (2018). Antecedentes de Presencia de Marea Roja en Costas Nacionales. Comisión Federal de Protección Contra Riesgos Sanitarios. Available at: https://www.gob.mx/cofepris/documentos/presencia-de-marearoja-en-costas-nacionales-durante- 2003 [accessed September 27, 2018].

Cortés-Altamirano, R., Hernández-Becerril, D. U., and Luna-Soria, R. (1995). Mareas rojas en México: una revisión. Rev. Latinoam. Microbiol. 37, 343-352.

Cortés-Altamirano, R., Muñoz-Cabrera, L., and Sotomayor-Navarro, O. (1993). Envenenamiento paralítico por mariscos (PSP), causado por el dinoflagelado
- Develop morphological, ecotoxicological, and genetic studies with strains from several geographical regions of Mexico and Central America, which are needed to accept or modify the current species taxonomic status, as well as, corroborate populations autoecology and toxicity.

\section{AUTHOR CONTRIBUTIONS}

The author participated in all the activities of research: data collection, analyses, interpretation of the results, and manuscript writing.

\section{FUNDING}

This work was supported by the CIBNOR project 20014 (Colección de Dinoflagelados Marinos).

\section{ACKNOWLEDGMENTS}

The author thank Dr. Andrea Murillo from Biotechnologika A2 for critically reading of the manuscript.

Pyrodinium bahamense var. compressum en la costa suroeste de México. An. Inst. Cienc. del Mar y Limnol. UNAM 20, 43-54.

Cortés-Altamirano, R., and Núñez-Pasten, A. (1992). Doce años (1979-1990) de registros de mareas rojas en la Bahía de Mazatlán, Sin., México. An. Inst. Cienc. Mar Limnol. Univ. Nac. Auton. Mex. 19, 113-121.

Cuellar-Martínez, T., Alonso-Rodríguez, R., Ruiz-Fernández, A. C., de Vernal, A., Morquecho, L., Limoges, A., et al. (2018). Environmental forcing on the flux of organic-walled dinoflagellate cysts in recent sediments from a subtropical lagoon in the Gulf of California. Sci. Total Environ. 621, 548-557. doi: 10.1016/ j.scitotenv.2017.11.269

Cuellar-Martínez, T. C. (2018). Distribución Temporal y Germinación de Quistes de Pyrodinium bahamense Plate, 1906 en Sedimentos Recientes de dos Lagunas Costeras del Golfo de California, México. Ph.D, thesis, Universidad Nacional Autónoma de México-Posgrado en Ciencias del Mar y Limnología, Ciudad de México.

de Vernal, A., Henry, M., and Bilodeau, G. (2010). Micropaleontological Preparation Techniques and Analyses. Les Cahiers du GEOTOP No 3, 3rd $E d n$. Available at: https://www.geotop.ca/upload/files/laboratoires/laboratoirede-micropaleontologie-et-palynologie-marine-uqam/Micropal_Methods_ 2010.pdf [accessed September 20, 2018].

Fu, F. X., Tatters, A. O., and Hutchins, D. A. (2012). Global change and the future of harmful algal blooms in the ocean. Mar. Ecol. Prog. Ser. 470, 207-233. doi: 10.3354/meps10047

Gárate-Lizárraga, I., Díaz-Ortiz, J. A., Pérez-Cruz, B., Alarcón-Romero, M. A., Chávez-Almazán, L. A., García-Barbosa, J. L., et al. (2011). A multi-species dinoflagellate bloom and shellfish toxicity in Costa Grande, Guerrero, Mexico (December, 2010). CICIMAR Oceánides 26, 67-71.

Gárate-Lizárraga, I., and González-Armas, R. (2011). Occurrence of Pyrodinium bahamense var. compressum along the southern coast of the Baja California Peninsula. Mar. Pollut. Bull. 62, 626-630. doi: 10.1016/j.marpolbul.2011.01.009 Gárate-Lizárraga, I., Pérez-Cruz, B., Días-Ortiz, J., and Band-Schmidt, C. J. (2008). Microalgas y biotoxinas marinas en las costas mexicanas. Conversus 9, 22-26.

Gárate-Lizárraga, I., Pérez-Cruz, B., Díaz-Ortíz, J. A., Alarcón-Tacuba, M., ChávezAlmazán, L. A., Alarcón-Romero, M. A., et al. (2012). Toxicity and paralytic toxin profile in Pyrodinium bahamense var. compressum and violet oyster in Bahía de Acapulco. Harmful Algae News 45, 2-3. 
Gárate-Lizárraga, I., Pérez-Cruz, B., Díaz-Ortiz, J. A., Alarcón-Tacuba, M. A., Alarcón-Romero, M. A., Chávez-Almazán, L. A., et al. (2013). Blooms of Pyrodinium bahamense var. compressum and rock oyster toxicity in Costa Chica, Guerrero, Mexico. CICIMAR Océanides 28, 37-42.

García-Mendoza, E., Quijano-Scheggia, S. I., Olivos-Ortiz, A., Núñez-Vázquez, E. J., and Pérez-Morales, A. (2016). "Introducción general," in Florecimientos Algales Nocivos en México, eds E. García-Mendoza, S. I. Quijano-Scheggia, A. Olivos-Ortiz, and E. J. Núñez-Vázquez (Ensenada: CICESE), 10-20.

Gómez-Aguirre, S. (1998a). First record of Pyrodinium bahamense (Dinoflagellata) in brackish waters of the Mexican Caribbean coast. An. Inst. Biol. Univ. Nac. Autón. Méx. Ser. Zool. 69, 121-123.

Gómez-Aguirre, S. (1998b). Red tide ocurrences recorded in Mexico from 1980 to 1992. An. Inst. Biol. Univ. Nac. Autón. Méx. Ser. Zool. 69, 13-22.

Guillard, R. R. L. (1978). "Counting slides," in Phytoplankton Manual Monographs on Oceanographic Methodology, Vol. 6, ed. A. Sournia (Paris: UNESCO), 184.

Hallegraeff, G. M. (2010). Ocean climate change, phytoplankton community responses, and harmful algal blooms: a formidable predictive challenge. J. Phycol. 46, 220-235. doi: 10.1111/j.1529-8817.2010.00815.x

Hasle, G. R. (1978). "Using the inverted microscope," in Phytoplankton Manual Monographs on Oceanographic Methodology, Vol. 6, ed. A. Sournia (Paris: UNESCO), 191-196.

Heisler, J., Glibert, P. M., Burkholder, J. M., Anderson, D. M., Cochlan, W., Dennison, W. C., et al. (2008). Eutrophication and harmful algal blooms: a scientific consensus. Harmful Algae 8, 3-13. doi: 10.1016/j.hal.2008.08.006

Hernández-Becerril, D. U., Alonso-Rodríguez, R., Álvarez-Góngora, C., BarónCampis, S. A., Ceballos-Corona, G., Herrera-Silveira, J., et al. (2007). Toxic and harmful marine phytoplankton and microalgae (HABs) in Mexican Coasts. J. Environ. Sci. Health A Tox. Hazard Subst. Environ. Eng. 42, 1349-1363. doi: 10.1080/10934520701480219

Lawrence, J. F., Niedzwiadek, B., and Menard, C. (2005). Quantitative determination of paralytic shellfish using prechromatographic oxidation and liquid chromatography with fluorescence detection: collaboratory study. J. AOAC Int. 88, 1714-1732.

Licea, S., Zamudio, M. E., Luna, R., and Soto, J. (2004). Free-living dinoflagellates in the southern Gulf of Mexico: report of data (1979-2002). Phycol. Res. 52, 419-428. doi: 10.1111/j.1440-183.2004.00364.x

Limoges, A., Kielt, J.-F., Radi, T., Ruíz-Fernandez, A. C., and de Vernal, A. (2010). Dinoflagellate cyst distribution in surface sediments along the southwestern Mexican coast $\left(14.76^{\circ} \mathrm{N}\right.$ to $\left.24.75^{\circ} \mathrm{N}\right)$. Mar. Micropaleontol. $76,104-123$. doi: 10.1016/j.marmicro.2010.06.003

Limoges, A., Londeix, L., and de Vernal, A. (2013). Organic-walled dinoflagellate cyst distribution in the Gulf of Mexico. Mar. Micropaleontol. 102, 51-68. doi: 10.1016/j.marmicro.2013.06.002

Lluch-Cota, S. E., Álvarez-Borrego, S., Santamaria-del Ángel, E. M., MullerKarger, F. E., and Hernandez-Vazquez, S. (1997). The Gulf of tehuantepec and adjacent areas: spatial and temporal variation of satellite-derived photosynthetic pigments. Cienc. Mar. 23, 329-340. doi: 10.7773/cm.v23i3.809

Maciel-Baltazar, E. (2015). Dinoflagelados (Dinoflagellata) tóxicos de la costa de Chiapas, México, Pacífico centro oriental. Cuadernos de Investigación UNED 7 , $39-48$.

Maclean, J. L. (1989). "An overview of Pyrodinium red tides in the western Pacific," in Biology, Epidemiology and Management of Pyrodinium Red Tides, eds G. M. Hallegraeff and J. L. Maclean (Manila: International Center for Living Aquatic Resources Management), 1-8.

Martínez-Hernández, E., and Hernández-Campos, H. (1991). Distribución de quistes de dinoflagelados y acritarcas en sedimentos holocénicos del Golfo de California. Paleontol. Mex. 57, 1-133.

Martínez-López, A., Ulloa-Pérez, E., and Escobedo-Urias, D. (2007). First record of vegetative cells of Pyrodinium bahamense (Gonyalucales: Goniodomataceae) in the Gulf of California. Pacific Sci. 61, 289-293. doi: 10.2984/1534-6188(2007) 61[289:FROVCO]2.0.CO;2

Matsuoka, K., and Fukuyo, Y. (2000). Guía Técnica Para el Estudio de Quistes de Dinoflagelados Actuales. Tokyo: WESTPAC-HAB/WESTPAC/ IOC.

McClain, C. R., Christian, J. R., Signorini, S. R., Lewis, M. R., Asanuma, I., Turk, D., et al. (2002). Satellite ocean-color observations of the tropical Pacific Ocean. Deep Sea Res. II 49, 2533-2560. doi: 10.1016/S0967-0645(02)00047-4

Meave-del Castillo, M. E., Zamudio-Reséndiz, M. E., and Castillo-Rivera, M. (2012). Riqueza fitoplanctónica de la bahía de Acapulco y zona costera aledaña, Guerrero, México. Acta Bot. Mex. 100, 405-487. doi: 10.21829/abm100. 2012.41
Mee, L. D., Espinosa, M., and Díaz, G. (1986). Paralytic shellfish poisoning with a Gymnodinium catenatum red tide on the Pacific Coast of Mexico. Mar. Environ. Res. 19, 77-92. doi: 10.1016/0141-1136(86)90040-1

Merino-Virgilio, F. C., Okolodkov, Y. B., Aguilar-Trujillo, A. C., Osorio-Moreno, I., and Herrera-Silveira, J. A. (2014). "Florecimientos algales nocivos en las aguas costeras del norte de Yucatán (2001-2013)," in Golfo de México, Contaminación e Impacto Ambiental: Diagnóstico y Tendencias, eds A. V. Botello, J. Rendón von Osten, J. A. Benítez, and G. Gold-Bouchot (Mérida: UAC), $161-180$.

Mertens, K. N., Wolny, J., Carbonell-Moore, C., Bogus, K., Ellegaard, M., Limoges, A., et al. (2015). Taxonomic re-examination of the toxic armored dinoflagellate Pyrodinium bahamense Plate 1906: can morphology or LSU sequencing separate $P$. bahamense var. compressum from var. bahamense? Harmful Algae 41, 1-24. doi: 10.1016/j.hal.2014.09.010

Morquecho, L. (2008). Morphology of Pyrodinium bahamense plate (Dinoflagellata) near Isla San José, Gulf of California, Mexico. Harmful Algae 7, 664-670. doi: 10.1016/j.hal.2008.02.003

Morquecho, L., Alonso-Rodríguez, R., Arreola-Lizárraga, J. A., and ReyesSalinas, A. (2012). Factors associated with moderate blooms of Pyrodinium bahamense in shallow and restricted subtropical lagoons in the Gulf of California. Bot. Mar. 55, 611-623. doi: 10.1515/bot-2012-0171

Morquecho, L., Alonso-Rodríguez, R., and Martínez-Tecuapacho, G. A. (2014). Cyst morphology, germination characteristics, and potential toxicity of Pyrodinium bahamense in the Gulf of California. Bot. Mar. 57, 303-314. doi: 10.1515/bot-2013-0121

Núñez-Vázquez, E. J., Band-Schmidt, C. J., Hernández-Sandoval, F. E., BustillosGuzmán, J. J., López-Cortés, D. J., et al. (2016). "Impactos de los FAN en la salud pública y animal (silvestres y de cultivo) en el Golfo de California," in Florecimientos Algales Nocivos en México, eds E. García-Mendoza, S. I. QuijanoScheggia, A. Olivos-Ortiz, and E. J. Núñez-Vázquez (Ensenada: CICESE), 196-212.

Osorio-Tafall, B. F. (1942). Notas sobre algunos dinoflagelados planctónicos marinos de México con descripción de nuevas especies. An. Esc. Nac. Cienc. Biol. 2, 435-447.

Peña-Manjarrez, J. L., Gaxiola-Castro, G., Helenes-Escamilla, J., and OrellanaCepeda, E. (2001). Cysts of Lingulodinium polyedrum, red tide producing organism in the Todos Santos Bay (Winter-Spring, 2000). Cienc. Mar. 27, 543-558. doi: $10.7773 / \mathrm{cm} . v 27 i 4.501$

Peña-Manjarrez, J. L., Helenes, J., Gaxiola-Castro, G., and Orellana-Cepeda, E. (2005). Dinoflagellate cysts and bloom events at Todos Santos Bay, Baja California, México, 1999-2000. Cont. Shelf. Res. 25, 1375-1393. doi: 10.1016/ j.csr.2005.02.002

Pennington, J. T., Mahoney, K. L., Kuwahara, V. S., Kolber, D. D., Calienes, R., and Chavez, F. P. (2006). Primary production in the eastern tropical Pacific: a review. Prog. Oceanogr. 69, 285-317. doi: 10.1016/j.pocean.2006.03.012

Phlips, E. J., Badylak, S., Bledsoe, E., and Cichra, M. (2006). Factors affecting the distribution of Pyrodinium bahamense var. bahamense in coastal waters of Florida. Mar. Ecol. Prog. Ser. 322, 99-115. doi: 10.3354/meps322099

Phlips, E. J., Badylak, S., Youn, S., and Kelley, K. (2004). The occurrence of potentially toxic dinoflagellates and diatoms in a subtropical lagoon, the Indian River Lagoon, Florida, USA. Harmful Algae 3, 39-49. doi: 10.1016/j.hal.2003. 08.003

Poot-Delgado, C. A. (2016). Florecimientos algales nocivos en las costas de Campeche, Golfo de México. Investigación y Ciencia de la Universidad Autónoma de Aguascalientes 68, 91-96.

Poot-Delgado, C. A., Rosado-García, P. I., and Guzmán-Noz, Y. A. (2014). "Fitoplancton marino potencialmente nocivo en las aguas costeras de Campeche," in Golfo de México, Contaminación e Impacto Ambiental: Diagnóstico y Tendencias, eds A. V. Botello, J. Rendón von Osten, J. A. Benítez, and G. Gold-Bouchot (Mérida: UAC), 117-132.

Ronsón-Paulin, J. A. (1999). Análisis retrospectivo y posibles causas de las mareas rojas tóxicas en el litoral del sureste mexicano (Guerrero, Oaxaca, Chiapas). Ciencia y Mar. 3, 49-55.

Saldate-Castañeda, O., Vázquez-Castellanos, J. L., Galván, J., SánchezAnguiano, A., and Nazar, A. (1991). Intoxicaciones por toxina paralizante de molusco en Oaxaca. Salud. Publica. Mex. 33, 240-247.

Seliger, H. H., Carpenter, J. H., Loftus, M., Biggley, W. H., and McElroy, W. D. (1971). Bioluminescence and phytoplankton successions in Bahia Fosforescente, Puerto Rico. Limnol. Oceanogr. 16, 608-622. doi: 10.4319/lo. 1971.16.4.0608 
Steidinger, K. A., Tester, L. S., and Taylor, F. J. R. (1980). A redescription of Pyrodinium bahamense var. compressa (Böhm) stat. nov. from Pacific red tides. Phycologia 19, 329-337. doi: 10.2216/i0031-8884-19-4-329.1

Strickland, J. D. H., and Parsons, T. R. (1972). A Practical Handbook of Sea-water Analysis. Ottawa: Canadian Science Publishing.

Terán-Suárez, J. M., Castro, G. V., Mayor-Nucamendi, H. F., and Brito-López, J. A. (2006). Florecimientos algales en tabasco. Salud en Tabasco 12, 414-422.

Throndsen, J. (1978). "Preservation and storage," in Phytoplankton Manual Monographs on Oceanographic Methodology, Vol. 6, ed. A. Sournia (Paris: UNESCO), 69-74.

Usup, G., Ahmad, A., Matsuoka, K., Lim, T., and Leaw, C. P. (2012). Biology, ecology and bloom dynamics of the toxic marine dinoflagellate Pyrodinium bahamense. Harmful Algae 14, 301-312. doi: 10.1016/j.hal.2011.10.026

Usup, G., and Azanza, R. V. (1998). "Physiology and bloom dynamics of the tropical dinoflagellate Pyrodinium bahamense," in Physiological Ecology of Harmful Algal Blooms, eds D. M. Anderson, A. D. Cembella, and G. M. Hallegraeff (Berlin: Springer Verlag), 81-94.

Vargas-Montero, M., Freer-Bustamante, E., Guzmán, J. C., and Vargas, J. C. (2008). Florecimientos de dinoflagelados nocivos en la costa Pacífica de Costa Rica. Hidrobiológica 18, 15-23.

Vásquez-Bedoya, L. F., Radi, T., Ruiz-Fernández, A. C., de Vernal, A., MachainCastillo, M. L., Kielt, J. F., et al. (2008). Organic-walled dinoflagellate cysts and benthic foraminifera in coastal sediments of the last century from the Gulf of
Tehuantepec, South Pacific Coast of Mexico. Mar. Micropaleontol. 68, 49-65. doi: 10.1016/j.marmicro.2008.03.002

Wall, D., and Dale, B. (1969). The "hystrichosphaerid" resting spore of the dinoflagellate Pyrodinium bahamense plate 1906. J. Phycol. 5, 140-149. doi: 10.1111/j.1529-8817.1969.tb02595.x

Walsh, J. J., Tomas, C. R., Steidinger, K. A., Lenes, J. M., Chen, F. R., Weisberg, R. H., et al. (2011). Imprudent fishing harvests and consequent trophic cascades on the West Florida shelf over the last half century: a harbinger of increased human deaths from paralytic shellfish poisoning along the southeastern United States, in response to oligotrophication? Cont. Shelf Res. 31, 891-911. doi: 10.1016/j.csr.2011. 02.007

Conflict of Interest Statement: The author declares that the research was conducted in the absence of any commercial or financial relationships that could be construed as a potential conflict of interest.

Copyright (C) 2019 Morquecho. This is an open-access article distributed under the terms of the Creative Commons Attribution License (CC BY). The use, distribution or reproduction in other forums is permitted, provided the original author(s) and the copyright owner(s) are credited and that the original publication in this journal is cited, in accordance with accepted academic practice. No use, distribution or reproduction is permitted which does not comply with these terms. 